UDC 544.65

\author{
V.S. Protsenko, L.S. Bobrova, F.I. Danilov
}

\title{
EFFECTS OF WATER AND SODIUM DODECYL SULFATE ADDITIVES ON Cr(III) IONS ELECTROREDUCTION IN A DEEP EUTECTIC SOLVENT
}

\author{
Ukrainian State University of Chemical Technology, Dnipro, Ukraine
}

\begin{abstract}
Kinetics of $\mathrm{Cr}$ (III) ions electroreduction in a deep eutectic solvent (ethaline) was studied by using electrochemical impedance spectroscopy. The influence of water and sodium dodecyl sulfate on the kinetic parameters was established. The developed equivalent circuit included polarization resistance of the electrochemical reaction, constant phase element and finite Warburg impedance. The respective parameters of the accepted equivalent circuit were calculated and discussed. The obtained results indicated that the charge transfer is a rate-determining step of an electrochemical reaction occurring on a heterogeneous electrode surface. An increase in content of water in electrolytes resulted in an increase in polarization resistance, indicating the deceleration of $\mathrm{Cr}$ (III) ions electroreduction due to the changes in $\mathrm{Cr}$ (III) speciation. In addition, the introduction of extra water caused an increase in the value of a capacitive component of electrochemical impedance because of a rearrangement of the double electrical layer. The polarization resistance of $\mathrm{Cr}$ (III) ion discharge was increased in the presence of sodium dodecylsulfate in electrolyte due to adsorption of dodecylsulfate anion on the electrode surface. A Warburg impedance component disappeared in electrolytes containing relatively high water content, which was associated with corresponding reduction of solution viscosity and acceleration of diffusion mass transfer.
\end{abstract}

Keywords: electroreduction, Cr(III) ion, electrochemical impedance, deep eutectic solvent, sodium dodecylsulfate, water.

DOI: $10.32434 / 0321-4095-2021-135-2-110-116$

\section{Introduction}

Deep eutectic solvents (DESs) is an emerging type of ionic liquids which is characterized by availability, low prices, ecological compatibility and a unique complex of physicochemical properties that are superior to those typical of both common organic solvents and water-based systems [1,2]. Kinetics and mechanism of electrochemical reduction of different metal ions in DES-based electrolytes were under consideration in a number of recent publications $[3,4]$. A special attention was paid to the electrochemical reduction of $\mathrm{Cr}$ (III) ions [5-9], since this reaction is an integral part of the total process of electrodeposition of chromium from trivalent chromium plating bath that is of paramount importance in the light of development of novel highperformance and eco-friendly metal finishing processes [10-13].

Earlier, the features of electroreduction of $\mathrm{Cr}(\mathrm{III})$ ions in a DES, ethaline (an eutectic mixture of choline chloride and ethylene glycol), and waterethaline mixtures were studied on a glassy carbon electrode [14]. Some kinetics characteristics were determined based on the registered voltammetry responses. It was established that the addition of extra water to the DES-based electrolyte appreciably affects the kinetics of charge transfer in electrochemical couple $\mathrm{Cr}(\mathrm{III}) / \mathrm{Cr}$ (II) as well as the transport characteristics of the ionic liquid under consideration. Thus, water can be considered a special additive to DES-containing plating electrolytes $[3,6,7,10,11,14]$. In addition, the application of traditional organic surfactants is of great interest, because they could strongly and favorably influence separate stages of an electrochemical process of metal deposition [12]. Unfortunately, there are no data on the effects of surfactants on the kinetics of $\mathrm{Cr}$ (III) ion electroreduction in DES-based electrochemical systems. 
The investigation of $\mathrm{Cr}(\mathrm{III})$ ions discharge was performed in a number of previous studies [6-10,14] by means of cyclic and linear voltammetry technique. However, the capabilities of this method are restricted; for instance, it cannot give detailed information about the state of the electrode surface. In this context, electrochemical impedance spectroscopy attracts close attention, since it allows determining exhaustive parameters of the electrochemical process and the state of the electrode surface even in cases of exclusively complicated reactions mechanisms.

Therefore, the aim of this work was to investigate the kinetics of $\mathrm{Cr}$ (III) ion electroreduction in DES-based electrochemical systems by means of electrochemical impedance spectroscopy technique. We established the effect of extra water on kinetic parameters of electrochemical reaction. In addition, we studied the influence of sodium dodecylsulfate (SD) on the rate of $\mathrm{Cr}$ (III) reduction. The choice of SD for our investigation was due to the fact that it is a typical surfactant used in trivalent chromium plating electrolytes [12]. The effects of various surfactants on the kinetic of electrochemical processes occurring in DES-based systems have been studied insufficiently.

\section{Experimental}

A eutectic mixture of choline chloride and 1,2-ethanediol (in the molar ratio of 1:2, respectively) was used in this study. This DES is also known as ethaline [1-3]. The preparation of ethaline and $\mathrm{Cr}(\mathrm{III})$-containing electrolyte based on ethaline was described elsewhere [14]. The content of residual moisture in ethaline was determined by Karl Fischer method and did not exceed $1 \%$. Sodium dodecylsulfate and water were dissolved directly in DES-based electrolytes.

Electrochemical measurements were conducted in a thermostated glass three-electrode cell at the temperature of $298 \mathrm{~K}$. An end face of a glassy carbon disk electrode $(\varnothing 5 \mathrm{~mm})$ was used as a working electrode, the electrode being embedded into Teflon cylinder. The surface of glassy carbon disk electrode was mechanically polished with alumina slurry, treated in hydrochloric acid solution for several minutes, washed with bidistilled water and dried. Then the electrode was inserted into an electrochemical cell. Pt gauze served as a counter electrode. The electrode potentials were registered against a silver wire pseudo-reference electrode [14].

Potentiostat Reference 3000 (Gamry) with automatic compensation of ohmic potential drop was applied to carry out electrochemical investigations. The electrochemical impedance spectra were recorded at open circuit potential at the $\mathrm{AC}$ voltage amplitude of $5 \mathrm{mV}$ in the frequency range of $0.01 \mathrm{~Hz}$ to $100 \mathrm{kHz}$. The obtained results were treated by Gamry Elchem Analyst software.

\section{Results and discussion}

\section{Effect of water additive}

Figure 1 demonstrates Nyquist plots recorded in $\mathrm{Cr}(\mathrm{III})$-containing ethaline at different content of water. As can be seen, Nyquist plots are flattened semicircles, which indicates that the charge transfer is a rate-determining step of an electrochemical reaction occurring on a heterogeneous electrode surface. Only for electrolyte without extra water (Fig. 1, curve 1), electrochemical impedance spectrum exhibits diffusion behavior at low frequencies revealing the presence of Warburg impedance.

To fit the obtained data, an equivalent circuit was used (inset in Fig. 1) which contains ohmic resistance of solution $\left(R_{s}\right)$, polarization resistance of the electrochemical process $\left(R_{c t}\right)$, constant phase element (CPE) and finite Warburg impedance $\left(\mathrm{W}_{\mathrm{D}}\right)$. The calculated parameters of the adopted equivalent circuit are summarized in Table 1 as a function of water content in electrolyte.

An increase in water content in DES-based electrolyte results in an increase in polarization resistance, $\mathrm{R}_{\mathrm{ct}}$, caused by deceleration of $\mathrm{Cr}$ (III) ions electroreduction. This observation is in good

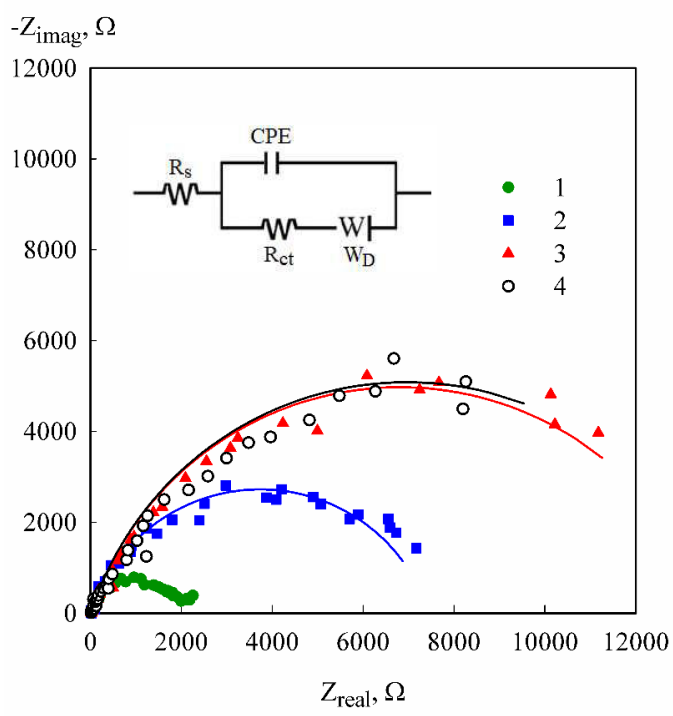

Figure 1. Nyquist plots recorded in solutions containing $0.05 \mathrm{M}$ $\mathrm{CrCl}_{3} \cdot 6 \mathrm{H}_{2} \mathrm{O}$ in ethaline at different content of extra water: 1 - without extra water, $2-10 \%, 3-15 \%, 4-20 \%$. Inset presents equivalent circuit used for simulating the electrochemical impedance of a solid electrode/solution interface 
Calculated parameters of electrochemical impedance for the systems containing $0.05 \mathrm{M} \mathrm{CrCl}_{3} \cdot 6 \mathrm{H}_{2} \mathrm{O}$ in ethaline at different content of water

\begin{tabular}{c|c|c|c|c|c|c}
\hline Water content, \% & $\mathrm{R}_{\mathrm{s}}, \Omega$ & $\mathrm{R}_{\mathrm{ct}}, \mathrm{k} \Omega \mathrm{cm}^{2}$ & $\mathrm{Q} \cdot 10^{6}, \Omega^{-1} \mathrm{~s}^{\mathrm{n}} \mathrm{cm}^{-2}$ & $\mathrm{n}$ & $\mathrm{Y}_{\mathrm{W}} \cdot 10^{3}, \Omega^{-1} \mathrm{~s}^{1 / 2}$ & $\mathrm{~B}, \mathrm{~s}^{1 / 2}$ \\
\hline- & 9.40 & 1.95 & 70 & 0.805 & 7.36 & 55.6 \\
\hline 10 & 7.20 & 7.45 & 230 & 0.804 & - & - \\
\hline 15 & 5.15 & 13.60 & 240 & 0.804 & - & - \\
\hline 20 & 3.70 & 13.90 & 400 & 0.804 & - & - \\
\hline
\end{tabular}

agreement with the findings reported earlier ${ }^{1}$ [14], according to those a decrease in the rate of charge transfer is associated with the changes in $\mathrm{Cr}(\mathrm{III})$ ions speciation. The introduction of water causes a gradual substitution of $\mathrm{Cl}^{-}$anions with water molecules in the first coordination sphere of chromium-containing complex ions [7]. The formation of chloride complexes promotes the charge transfer in the electrochemical reaction $\mathrm{Cr}(\mathrm{III})+\mathrm{e}^{-} \rightarrow \mathrm{Cr}(\mathrm{II})$, whereas aqua complexes of $\mathrm{Cr}(\mathrm{III})$ are discharged relatively slowly.

Considering the effect of water on the parameters characterizing the constant phase element, it should be noted that the electrochemical impedance of the CPE is expressed by the following equation:

$$
Z_{\mathrm{CPE}}=\left[\mathrm{Q}(\mathrm{j} \omega)^{\mathrm{n}}\right]^{-1}
$$

where $\mathrm{Q}$ is a constant reflecting the capacitive component of electrochemical impedance, $\mathrm{j}=\sqrt{-1}$ is the imaginary unit, $\omega=2 \pi \mathrm{f}$ is the angular frequency, and $\mathrm{n}$ is the dimensionless empirical parameters denoting a phase deviation.

Commonly, the value of $\mathrm{n}$ is attributed to the energy and geometric heterogeneity of the electrode surface. As expected, the change in water content has no effect on this parameter, since the state of the glassy carbon electrode cannot be altered by the introduction of water. The calculated value of $n$ is about 0.8 , which is appreciably less than unity, indicating that the surface of a glassy carbon electrode used in this work deviates from the state of a completely homogeneous electrode.

It should be observed that the value of $\mathrm{Q}$, which is usually ascribed to the capacitive component of electrochemical impedance, is increased with increasing water concentration (Table 1). The value of Q obtained for the systems without extra water is close to that reported earlier for differential capacity of solid electrodes in some deep eutectic solvents [15]. However, parameter Q grows when the content of water in electrolytes increases. It might be supposed that a gradual substitution of ions and/or molecules of organic constituents in a double electrical layer by water molecules, having higher dielectric constant, causes an observed increase in the capacitive component $\mathrm{Q}$. Thus, the changes in $\mathrm{Q}$ parameter can be associated with a rearrangement of the double electrical layer.

As far as a finite Warburg impedance is concerned, it can be given as follows:

$$
\mathrm{Z}_{\mathrm{W}}=\frac{1}{\mathrm{Y}_{\mathrm{W}}} \tanh [\mathrm{B} \sqrt{\mathrm{j} \omega}]
$$

where $Y_{w}$ is a constant, and $\mathrm{B}=\frac{\delta}{\sqrt{\mathrm{D}}}$, where $\delta$ is the thickness of the diffusion layer and $\mathrm{D}$ is the diffusion coefficient.

Our calculations show the presence of a Warburg impedance component for the solutions without any extra water. This may be due to a decelerated diffusion of $\mathrm{Cr}$ (III) ions to the electrode surface. However, all these diffusion limitations disappear in electrolytes containing additional water, which is resulted from a corresponding reduction of solution viscosity and acceleration of diffusion mass transfer [6,14]; accordingly, a Warburg impedance component vanishes.

\section{Effect of sodium dodecylsulfate additive}

Electrochemical impedance spectra obtained in DES-based electrolytes containing sodium dodecylsulfate at various water contents are shown in Fig. 2. Their shape is similar to that presented in Fig. 1, implying that the above equivalent circuit is also valid in this case. The calculated parameters of electrochemical impedance are given in Table 2.

As would be expected, the variation in SD content in electrolytes had no effect on the value of dimensionless empirical parameter $\mathrm{n}$. At the same time, an increase in the SD concentration caused a decrease in the values of capacitive component $Q$,

\footnotetext{
${ }^{1}$ The corresponding polarization curves showing the effect of water on the kinetics of $\mathrm{Cr}(\mathrm{III})$ electroreduction can be seen in ref. [14].
} 


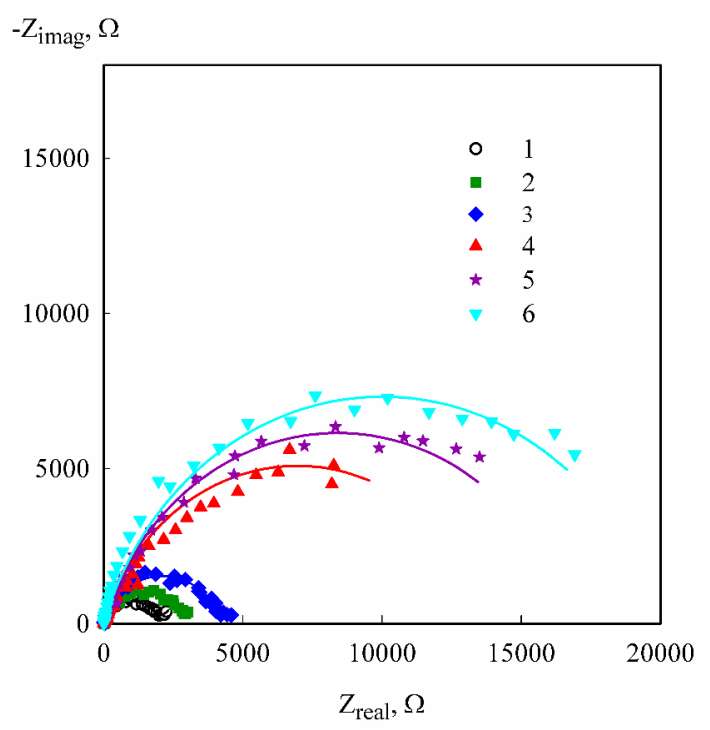

Figure 2. Nyquist plots recorded in solutions containing 0.05 $\mathrm{M} \mathrm{CrCl}_{3} \cdot 6 \mathrm{H}_{2} \mathrm{O}$ in ethaline at different content of sodium dodecylsulfate $\left(\mathrm{mol} \mathrm{m}^{-3}\right): 1$ and $4-$ without $\mathrm{SD} ; 2$ and $5-0.001 ; 3$ and $6-0.05$. The content of water: 1,2 and 3 - without extra water; 4,5 and $6-20 \%$ which can be caused by the adsorption of dodecylsulfate anion on the electrode surface. Other conditions being equal, the introduction of additional water led to an increase in the value of parameter $Q$ (Table 2).

It should be observed that the introduction of sodium dodecylsulfate into the DES-based electrolyte results in an increase in the polarization resistance of electrochemical reaction $\mathrm{Cr}(\mathrm{III})+\mathrm{e}^{-} \rightarrow \mathrm{Cr}$ (II). The polarization curves registered in the same electrolytes confirm this conclusion (Fig. 3). Indeed, their ascending (exponential) cathodic segments corresponding to slow charge transfer shift towards negative potentials, indicating deceleration of electrochemical process, both in electrolytes without any extra water and in those containing some extra water. We think that the obtained results can be interpreted in terms of adsorption of dodecylsulfate anion on the electrode surface leading to inhibition of cathodic reaction.

Let us note that the adsorption of an anionic surfactant in the course of electroreduction of cations

Table 2

Calculated parameters of electrochemical impedance for the systems containing $0.05 \mathrm{M} \mathrm{CrCl}_{3} \cdot 6 \mathrm{H}_{2} \mathrm{O}$ in ethaline at different contents of water and sodium dodecylsulfate

\begin{tabular}{c|c|c|c|c|c|c|c}
\hline $\begin{array}{c}\text { Content of } \\
\text { water, \% }\end{array}$ & $\begin{array}{c}\text { Content of sodium dodecyl sulfate, } \\
\mathrm{mol} \mathrm{dm}^{-3}\end{array}$ & $\mathrm{R}_{\mathrm{s}}, \Omega$ & $\begin{array}{c}\mathrm{R}_{\mathrm{ct},} \\
\mathrm{k} \Omega \mathrm{cm}^{2}\end{array}$ & $\begin{array}{c}\mathrm{Q} \cdot 10^{6}, \\
\Omega^{-1} \mathrm{~s}^{\mathrm{n}} \mathrm{cm}^{-2}\end{array}$ & $\mathrm{n}$ & $\begin{array}{c}\mathrm{Y}_{\mathrm{W}} \cdot 10^{3}, \\
\Omega^{-1} \mathrm{~s}^{1 / 2}\end{array}$ & $\mathrm{~B}, \mathrm{~s}^{1 / 2}$ \\
\hline- & - & 9.40 & 1.95 & 70 & 0.805 & 7.36 & 55.6 \\
\hline- & 0.001 & 9.35 & 2.78 & 40 & 0.804 & 7.07 & 40.6 \\
\hline- & 0.05 & 9.30 & 4.15 & 25 & 0.804 & 6.71 & 37.6 \\
\hline 20 & - & 3.70 & 13.90 & 400 & 0.804 & - & - \\
\hline 20 & 0.001 & 3.60 & 16.80 & 220 & 0.804 & - & - \\
\hline 20 & 0.05 & 3.60 & 20.00 & 160 & 0.804 & - & - \\
\hline
\end{tabular}
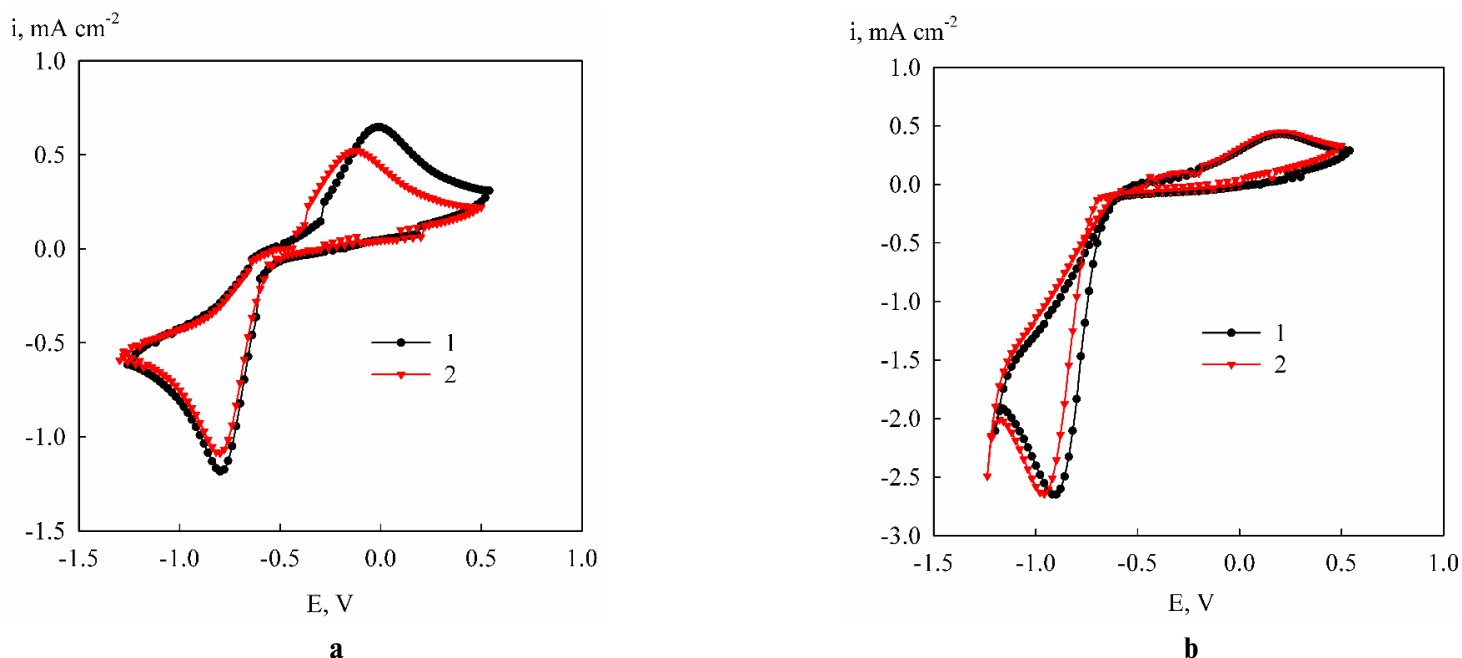

Figure 3. Polarization curves recorded on glassy carbon electrode in solutions containing $0.05 \mathrm{M} \mathrm{CrCl}_{3} \cdot 6 \mathrm{H}_{2} \mathrm{O}$ in ethaline at different content of sodium dodecylsulfate: $1-$ without $\mathrm{SD} ; 2-0.001 \mathrm{~mol} \mathrm{~m}^{-3}$. The content of water: a - without extra water; $\mathrm{b}-20 \%$. Scan rate $50 \mathrm{mV} \mathrm{s}^{-1}$

Effects of water and sodium dodecyl sulfate additives on $\mathrm{Cr}$ (III) ions electroreduction in a deep eutectic 
implies several different effects [16]: inhibiting steric factor, change in the potential in the localization plane of the activated complex, and the electrostatic and chemical interactions of the activated complex with the adsorption layer. In our opinion, the inhibition steric factor prevails in the case under study.

The presence of Warburg impedance component was observed for the systems without extra water. At higher water content, Warburg impedance disappeared completely due to elimination of mass transfer limitations (see above).

\section{Conclusions}

The effect of water and a typical surfactant, sodium dodecylsulfate, on the kinetics of the electroreduction of $\mathrm{Cr}$ (III) ions in a deep eutectic solvent, ethaline, was studied by electrochemical impedance spectroscopy using a glassy carbon electrode. Ii was shown that the rate of electrochemical reaction is controlled by the charge transfer and occurs on heterogeneous electrode surface. The introduction of extra water into the DES-based system causes an increase in polarization resistance of the charge transfer, indicating the deceleration of $\mathrm{Cr}$ (III) ions electroreduction. This effect is associated with changes in $\mathrm{Cr}$ (III) speciation.

DES-based system without any additional water demonstrated the presence of a Warburg impedance component implying some diffusion limitations. Due to a decrease in electrolyte viscosity, a Warburg impedance component vanished in electrolytes containing extra water.

The introduction of sodium dodecylsulfate resulted in a deceleration of $\mathrm{Cr}$ (III) electroreduction because of adsorption of dodecylsulfate anion on the electrode surface. The inhibitory action of sodium dodecylsulfate was observed both in electrolytes without extra water and in solution containing some additional water.

\section{REFERENCES}

1. Smith E.L., Abbott A.P., Ryder K.S. Deep eutectic solvents (DESs) and their applications // Chem. Rev. - 2014. - Vol.114. - P.11060-11082.

2. Deep eutectic solvents: syntheses, properties and applications / Zhang Q., Vigier K.D.O., Royer S., Jerome F. // Chem. Soc. Rev. - 2012. - Vol.41. - P.7108-7146.

3. Effect of water on the electrodeposition of copper on nickel in deep eutectic solvents / Al-Murshedi A.Y.M., Hartley J.M., Abbott A.P., Ryder K.S. // Trans. Inst. Met. Finish. - 2019. Vol.97. - P.321-329.
4. Influence of chloride ion on zinc electrodeposition from choline chloride based deep eutectic solvent / Wang X., Xu C., Liu H., Huang M., Ren X., Wang S., Hua Y., Zhang Q., Ru J. // Ionics. - 2020. - Vol.26. - P.1483-1490.

5. Mechanism and kinetics of chromium electrochemical nucleation and growth from a choline chloride/ethylene glycol deep eutectic solvent / Mejia-Caballero I., Aldana-Gonzalez J., Manh T.L., Romero-Romo M., Arce-Estrada E.M., CamposSilva I., Ramirez-Silva M.T., Palomar-Pardave M. // J. Electrochem. Soc. - 2018. - Vol.165. - P.D393-D401.

6. Speciation, conductivities, diffusivities, and electrochemical reduction as a function of water content in mixtures of hydrated chromium chloride/choline chloride / McCalman D.C., Sun L., Zhang Y., Brennecke J.F., Maginn E.J., Schneider W.F. // J. Phys. Chem. B. - 2015. - Vol.119. P.6018-6023.

7. Combining MCR-ALS and EXAFS as tools for speciation of highly chlorinated chromium(III) in mixtures of deep eutectic solvents and water / Verdonck T., Verpoort P., De Strycker J., De Cleene A., Banerjee D., Nockemann P., Van Deun R., Van Hecke K. // Dalton Trans. - 2019. - Vol.48. - P.2318-2327.

8. Speciation, physical and electrolytic properties of eutectic mixtures based on $\mathrm{CrCl}_{3} \cdot 6 \mathrm{H}_{2} \mathrm{O}$ and urea / Abbott A.P., Al-Barzinjy A.A., Abbott P.D., Frish G., Harris R.C., Hartley J., Ryder K.S. // Phys. Chem. Chem. Phys. - 2014 - Vol.16. P.9047-9055.

9. Ferreira E.S.C., Pereira C.M., Silva A.F. Electrochemical studies of metallic chromium electrodeposition from a $\mathrm{Cr}$ (III) bath // J. Electroanal. Chem. - 2013. - Vol.707. - P.52-58.

10. Electrodeposition of chromium coatings from a choline chloride based ionic liquid with the addition of water / Protsenko V.S., Bobrova L.S., Baskevich A.S., Korniy S.A., Danilov F.I. // J. Chem. Technol. Metall. - 2018. - Vol.53. - P.906-915.

11. Protsenko V., Bobrova L., Danilov F. Trivalent chromium electrodeposition using a deep eutectic solvent // Anti-Corros. Methods Mater. - 2018. - Vol.65. - P.499-505.

12. Protsenko V.S., Danilov F.I. Chromium electroplating from trivalent chromium baths as an environmentally friendly alternative to hazardous hexavalent chromium baths: comparative study on advantages and disadvantages // Clean Technol. Environ. Policy. - 2014. - Vol.16. - P.1201-1206.

13. Danilov F.I., Protsenko V.S., Butyrina T.E. Chromium electrodeposition kinetics in solutions of $\mathrm{Cr}$ (III) complex ions // Russ. J. Electrochem. - 2001. - Vol.37. - P.704-709.

14. Kinetics of $\mathrm{Cr}(\mathrm{III})$ ions discharge in solutions based on a deep eutectic solvent (ethaline): effect of water addition / Protsenko V., Bobrova L., Kityk A., Danilov F. // J. Electroanal. Chem. - 2020. - Vol.864. - Article No. 114086.

15. Differential capacity of a deep eutectic solvent based on choline chloride and glycerol on solid electrodes / Figueiredo M., Gomes C., Costa R., Martins A., Pereira C.M., Silva F. // Electrochim. Acta. - 2009. - Vol.54. - P.2630-2634. 
16. Danilov F., Obraztsov V., Kapitonov A. The inhibiting effect of organic substances at polycrystalline and amalgam electrodes // J. Electroanal. Chem. - 2003. - Vol.552. - P.69-76.

Received 06.01.2021

\section{ВПЛИВ ДОБАВОК ВОДИ І НАТРІЙ ДОДЕЦИЛСУЛЬФАТУ НА ЕЛЕКТРОВІДНОВЛЕННЯ IOНIВ Cr(III) В НИЗЬКОТЕМПЕРАТУРНОМУ ЕВТЕКТИЧНОМУ РОЗЧИННИКУ}

\section{В.С. Проценко, Л.С. Боброва, Ф.Й. Данилов}

Кінетика електровідновлення іонів Сr(III) в низькотемпературному евтектичному розчиннику (ethaline) була досліджена методом спектроскопії електродного імпедансу. Встановлено закономірності впливу води і натрій додецилсульфату на кінетичні параметри. Запропонована еквівалентна електрична схема, що включає поляризаційний опір електрохімічної реакції, елемент сталої фази і кінцевий імпеданс Варбурга. Обчислені і обговорені відповідні параметри прийнятої еквівалентної схеми. Одержані результати вказують на те, що уповільненою стадією електрохімічної реакції $€$ перенесення заряду, що відбувається на гетерогенній електродній поверхні. Збільшення вмісту води в електролітах приводить до зростання поляризаційного опору, вказуючи на гальмування електровідновлення іонів $\mathrm{Cr}$ (III) унаслідок змін у складі комплексів Сr(III). Окрім того, введення додаткової води викликає збільшення значення ємкісного компонента електродного імпедансу у зв'язку із перебудовою подвійного електричного шару. Поляризаційний опір розряду іонів $\mathrm{Cr}(\mathrm{III})$ підвищувався за присутності натрій додецилсульфату в електроліті унаслідок адсорбції додецилсульфат-аніонів на електродній поверхні. Імпеданс Варбурга зникає у електролітах, що містять відносно велику кількість води, що пов'язане із відповідним зниженням в'язкості розчину і прискоренням дифузійного масоперенесення.

Ключові слова: електровідновлення; іони $\mathrm{Cr}(\mathrm{III})$; електродний імпеданс; низькотемпературний евтектичний розчинник; натрій додецилсульфат; вода.

\section{EFFECTS OF WATER AND SODIUM DODECYL SULFATE ADDITIVES ON Cr(III) IONS ELECTROREDUCTION IN A DEEP EUTECTIC SOLVENT}

\section{V.S. Protsenko ", L.S. Bobrova, F.I. Danilov \\ Ukrainian State University of Chemical Technology, Dnipro, Ukraine}

\section{* e-mail: Vprotsenko7@gmail.com}

Kinetics of $\mathrm{Cr}$ (III) ions electroreduction in a deep eutectic solvent (ethaline) was studied by using electrochemical impedance spectroscopy. The influence of water and sodium dodecyl sulfate on the kinetic parameters was established. The developed equivalent circuit included polarization resistance of the electrochemical reaction, constant phase element and finite Warburg impedance. The respective parameters of the accepted equivalent circuit were calculated and discussed. The obtained results indicated that the charge transfer is a rate-determining step of an electrochemical reaction occurring on a heterogeneous electrode surface. An increase in content of water in electrolytes resulted in an increase in polarization resistance, indicating the deceleration of $\mathrm{Cr}(\mathrm{III})$ ions electroreduction due to the changes in $\mathrm{Cr}(\mathrm{III})$ speciation. In addition, the introduction of extra water caused an increase in the value of a capacitive component of electrochemical impedance because of a rearrangement of the double electrical layer. The polarization resistance of $\mathrm{Cr}$ (III) ion discharge was increased in the presence of sodium dodecylsulfate in electrolyte due to adsorption of dodecylsulfate anion on the electrode surface. A Warburg impedance component disappeared in electrolytes containing relatively high water content, which was associated with corresponding reduction of solution viscosity and acceleration of diffusion mass transfer.

Keywords: electroreduction; $\mathrm{Cr}$ (III) ion; electrochemical impedance; deep eutectic solvent; sodium dodecylsulfate; water.

\section{REFERENCES}

1. Smith EL, Abbott AP, Ryder KS. Deep eutectic solvents (DESs) and their applications. Chem Rev. 2014; 114: 11060-11082. doi: $10.1021 / \mathrm{cr} 300162 \mathrm{p}$.

2. Zhang Q, Vigier KDO, Royer S, Jerome F. Deep eutectic solvents: syntheses, properties and applications. Chem Soc Rev. 2012; 41: 7108-7146. doi: 10.1039/c2cs35178a.

3. Al-Murshedi AYM, Hartley JM, Abbott AP, Ryder KS. Effect of water on the electrodeposition of copper on nickel in deep eutectic solvents. Trans Inst Met Finish. 2019; 97: 321-329. doi: 10.1080/00202967.2019.1671062.

4. Wang X, Xu C, Liu H, Huang M, Ren X, Wang S, et al. Influence of chloride ion on zinc electrodeposition from choline chloride based deep eutectic solvent. Ionics. 2020; 26: 1483-1490. doi: 10.1007/s11581-019-03293-x.

5. Mejia-Caballero I, Aldana-Gonzalez J, Manh TL, Romero-Romo M, Arce-Estrada EM, Campos-Silva I, et al. Mechanism and kinetics of chromium electrochemical nucleation and growth from a choline chloride/ethylene glycol deep eutectic solvent. J Electrochem Soc. 2018; 165: D393-D401. doi: 10.1149/2.0851809jes.

6. McCalman DC, Sun L, Zhang Y, Brennecke JF, Maginn EJ, Schneider WF. Speciation, conductivities, diffusivities, and electrochemical reduction as a function of water content in mixtures of hydrated chromium chloride/choline chloride. J Phys Chem B. 2015; 119: 6018-6023. doi: 10.1021/acs.jpcb.5b01986.

7. Verdonck T, Verpoort P, De Strycker J, De Cleene A, Banerjee D, Nockemann P, et al. Combining MCR-ALS and EXAFS as tools for speciation of highly chlorinated chromium(III) in mixtures of deep eutectic solvents and water. Dalton Trans. 2019; 48: 2318-2327. doi: 10.1039/c8dt04292f.

8. Abbott AP, Al-Barzinjy AA, Abbott PD, Frish G, Harris RC, Hartley J, et al. Speciation, physical and electrolytic properties of eutectic mixtures based on $\mathrm{CrCl}_{3} \cdot 6 \mathrm{H}_{2} \mathrm{O}$ and urea. Phys Chem Chem Phys. 2014; 16: 9047-9055. doi: 10.1039/c4cp00057a.

9. Ferreira ESC, Pereira CM, Silva AF. Electrochemical studies of metallic chromium electrodeposition from a $\mathrm{Cr}$ (III) bath. J Electroanal Chem. 2013; 707: 52-58.

doi: 10.1016/j.jelechem.2013.08.005.

10. Protsenko VS, Bobrova LS, Baskevich AS, Korniy SA, Danilov FI. Electrodeposition of chromium coatings from a choline chloride based ionic liquid with the addition of water. J Chem Technol Metall. 2018; 53(5): 906-915. 
11. Protsenko V, Bobrova L, Danilov F. Trivalent chromium electrodeposition using a deep eutectic solvent. AntiCorros Methods Mater. 2018; 65: 499-505.

doi: 10.1108/ACMM-05-2018-1946.

12. Protsenko VS, Danilov FI. Chromium electroplating from trivalent chromium baths as an environmentally friendly alternative to hazardous hexavalent chromium baths: comparative study on advantages and disadvantages. Clean Technol Environ Policy. 2014; 16: 1201-1206. doi: 10.1007/s10098-014-0711-1.

13. Danilov FI, Protsenko VS, Butyrina TE. Chromium electrodeposition kinetics in solutions of $\mathrm{Cr}$ (III) complex ions. Russ J Electrochem. 2001; 37: 704-709.

doi: 10.1023/A:1016764600973.

14. Protsenko V, Bobrova L, Kityk A, Danilov F. Kinetics of $\mathrm{Cr}$ (III) ions discharge in solutions based on a deep eutectic solvent (ethaline): effect of water addition. $J$ Electroanal Chem. 2020; 864: 114086. doi: 10.1016/j.jelechem.2020.114086.

15. Figueiredo M, Gomes C, Costa R, Martins A, Pereira CM, Silva F. Differential capacity of a deep eutectic solvent based on choline chloride and glycerol on solid electrodes. Electrochim Acta. 2009; 54: 2630-2634.

doi: $10.1016 /$ j.electacta.2008.10.074.

16. Danilov F, Obraztsov V, Kapitonov A. The inhibiting effect of organic substances at polycrystalline and amalgam electrodes. J Electroanal Chem. 2003; 552: 69-76.

doi: 10.1016/S0022-0728(03)00182-7. 